\title{
Short communication: Leaf architecture of 35 species of Dipterocarpaceae cultivated in Forest Area with Special Purposes in Carita, Banten, Indonesia
}

\author{
ALNUS MEINATA, MOHAMMAD NA'IEM, DWI TYANINGSIH ADRIYANTI, ATUS SYAHBUDIN \\ Faculty of Forestry, Universitas Gadjah Mada. Jl Agro No. 1, Bulaksumur, Sleman 55281, Yogyakarta, Indonesia. \\ Tel.: +62-274-550541, Fax.: +62-274-550541, ’email: dtadrianti@ugm.ac.id, meinataa@gmail.com
}

Manuscript received: 18 March 2021. Revision accepted: 27 June 2021.

\begin{abstract}
MeinataA, Na'iem M, Adriyanti DT, Syahbudin A. 2021. Short communication: Leaf architecture of 35 species of Dipterocarpaceae cultivated in Forest Area with Special Purposes in Carita, Banten, Indonesia. Biodiversitas 22: 2952-2960. Dipterocarpaceae is a major commercial timber characterized by high unbranched bole, paired stipules, and winged fruit. The identification process in the family becomes problematic, in cases where the generative organ is absent. Therefore, a new approach needs to be established to address any misidentification leading to improper utilization. This study aims to determine the leaf architecture in 35 species of Dipterocarpaceae cultivated in Forest Area with Special Purposes (KHDTK) Carita, Banten, Indonesia. The ten leaf samples collected were the third and fourth leaves from terminal shoots of a single tree of each species. Subsequently, the data were observed and measured based on the 17 morphological characters. Each character was then scored and analyzed using multivariate analyses cluster to determine the relationship between species. Dipterocarpaceae generally has pinnate leaf category, geniculate petiole, and entire margin. Furthermore, the phenon line in the dendrogram is cut at 0.695 similarity level to establish meaningful interpretation. The 35 species observed were grouped into 4 major clusters. Small leaf group, inconsistent tertiary vein pattern group, symmetrical leaves with cordate base leaf group, and other groups that do not resemble mentioned characters. The key determination comprised 34 couplets with three characters repeated due to limited descriptors.
\end{abstract}

Keywords: Banten, cluster analysis, Dipterocarpaceae, leaf architecture, venation.

\section{INTRODUCTION}

Dipterocarpaceae is a tropical rainforest timber species group widely found in Peninsular Malaysia, Sumatra, Java, Lesser Sunda Islands, Lombok, Borneo, the Philippines, Celebes, Moluccas, Papua New Guinea, and Bismarcks (Ashton 1982). According to Dayanandan et al. (1999), Dipterocarpaceae is one of the largest families comprising 523 species belonging to 17 genera worldwide. Meanwhile, most of these genera (76\%) occupy the Malesian region, especially Indonesia in a large variety of habitats, from inland to coastal as well as swampy to dryland areas (Purwaningsih 2004), and generally grow in wet tropical regions with rainfall above $1000 \mathrm{~mm}^{\text {year }}{ }^{-1}$ or dry season lasting below 6 months (Appanah and Turnbull 1998)). Species of Dipterocarpaceae mostly exist in lowland rainforests at altitude 0-1000 $\mathrm{m}$ asl. (Ashton 1982; Purwaningsih 2004), and usually grow as emergent trees in hills and slopes above $50 \mathrm{~m}$ tall (Appanah and Turnbull 1998).

The Dipterocarpaceae has irregular flowering and uncertain fruiting. Therefore, studies related to species within the family have encountered difficulty in identification, due to the absence of flowers and fruit (Ashton 1982; Newman et al. 1998). Members of the Cotylelobium, Dipterocarpus, Dryobalanops, Parashorea, and Vatica are largely only identifiable based on flowers and fruit. Therefore, recognizing members of this family based on the use of vegetative organs is unlikely (Whitmore 1962). Furthermore, misidentification is bound to result in improper utilization of timbers, for instance, mersawa wood (Anisoptera spp.) and this is unsuitable for heavy construction (Pulan and Buot Jr. 2014).

Leaves are as important as the reproductive organs for species identification, particularly for dicotyledonous species (Hickey 1973). Leaf architecture is a term used to represent elements on leaves, including the pattern, margin, shapes, and gland position (Barral et al. 2013). A study by Huiet et al. (2018) showed pattern in leaves also reveal evolution traits. Meanwhile, Hickey (1999) mentioned the use of architecture referring to formations and constructions generating the leaf venation. The taxonomist's attention to the leaves' size comparison begins with the theory stating the shapes are not affected by the environment (Balduzzi et al. 2017) and the venation is derived genetically (Dickinson et al. 1987; Mishra et al. 2010). Due to the availability and variations, the leaf is organ-rich information and the source of taxonomy data (Kareem et al. 2018; Masungsong et al. 2019). Leaf venation is also used to delineate between two confusing Dipterocarpaceae species in the same genera (Mazo and Aribal 2020). Therefore, the study on leaf architecture is a new approach providing information on disconcerting species and an important aspect of identification (Swaminathan et al. 2012), as leaves are genetically fixed (Roth-Nebelsick et al. 2001). 
Leaf architecture is a breakthrough to confirm a species based on venation pattern (Buot Jr. 2020). A leaf's venation pattern is a significant character in the taxonomy's determination (Inamdar and Murthy 1978; Celadiña et al. 2012; Pulan and Buot Jr. 2014; Buot Jr. 2020; Hernandez et al. 2020). Therefore, investigations are required to understand the leaf architecture of Dipterocarpaceae species, for taxonomy and forestry. This study aims to determine the leaf architecture in 35 species of Dipterocarpaceae cultivated in Forest Area with Special Purposes (KHDTK) Carita, Banten, Indonesia.

\section{MATERIALS AND METHODS}

\section{Study area}

Leaf specimens were collected on February 3-10, 2019, in Forest Area with Special Purposes (KHDTK) Carita plot 70 and 71 with the red dots, Labuan Sub-district, Pandeglang District, Banten, Indonesia (Figure 1). The forest originated from the Forest and Nature Conservation Research and Development (FNCRDC) pseudo-in-situ planting trial project in 1956, where pseudo-in-situ refers to a conservation method adapting ex-situ conservation combined with the suited plot environment condition similar to the site of origin (Thielges et al. 2001).
According to Schmidt and Ferguson (1951), the area has climate type $\mathrm{A}$, a temperature of $23-32^{\circ} \mathrm{C}$, an average annual rainfall reaching $3900 \mathrm{~mm}$, a humidity level between $77 \%$ and $85 \%$, and an altitude of 50 asl. with the total area \pm 5 ha (https://www.fordamof.org/files/Puskonser_Carita.pdf). Carita Forest has greyish alluvial soil type, with low organic layer and high alkali maturity, as well as low permeability and varying soil acidity (Rimbawanto 2006). Subsequently, morphological observations of leaf architecture were conducted in the Tree Improvement Laboratory, Faculty of Forestry, Gadjah Mada University from March to April 2019.

\section{Leaf collection}

Leaf sampling was carried out using the exploration method described by Rugayah et al. (2004). The method used involved conducting an exploration of the existing area to determine the targeted species and selecting a mature leaf, the third or fourth leaf from the terminal buds of 10 leaf blades, from each species (Jessica and Buot Jr. 2014). Specimens were collected from the complete leaf organs and branches of the Dipterocarpaceae family for identification purposes.

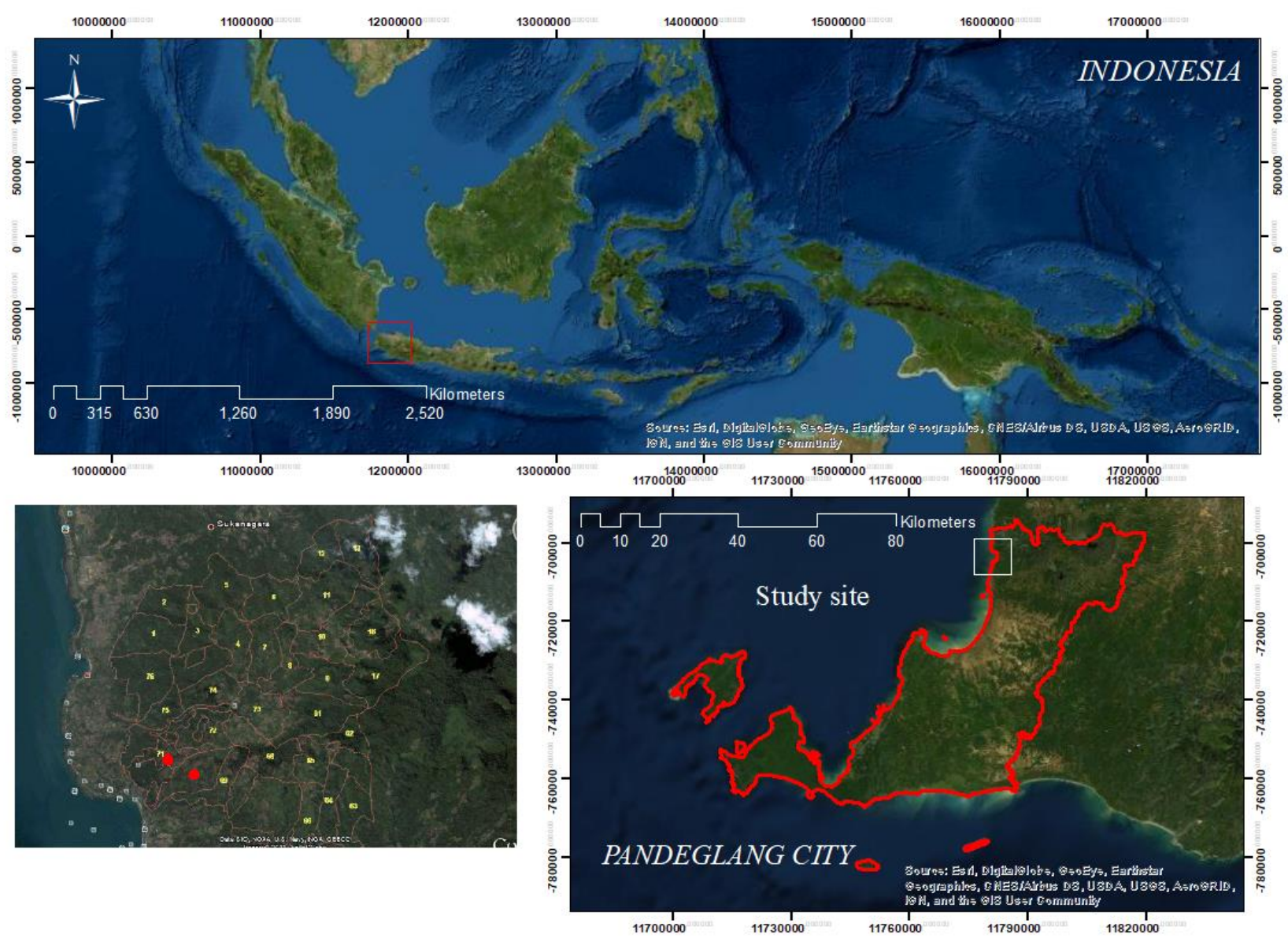

Figure 1. Study area in Forest Area with Special Purposes (KHDTK) Carita, Banten, Indonesia 


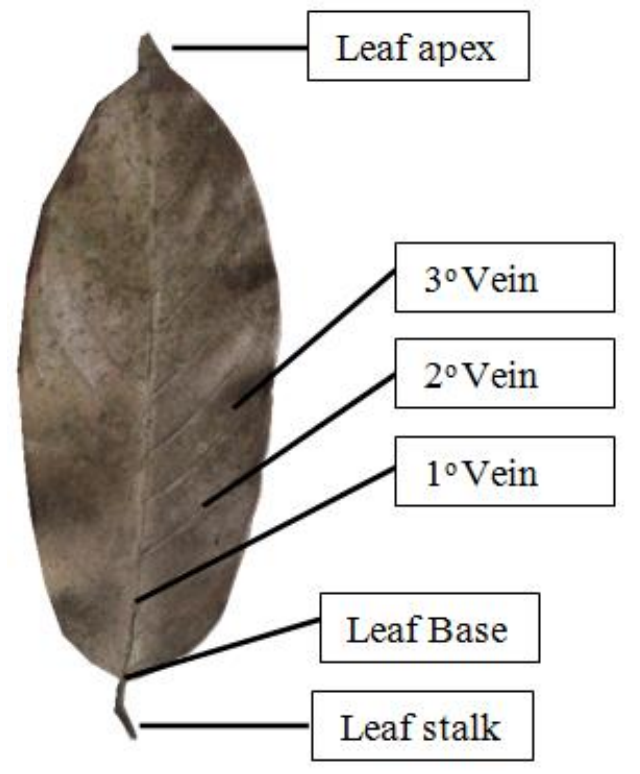

Figure 2. Venation order in single Dipterocarpaceae leaf (Shorea almon) blade, including the leaf stalk, leaf base, 1o, 2o, 3o vein order, and leaf apex

\section{Sample identification}

Identification of species names was conducted to provide information on the leaves, after oven-drying for approximately 3 days or until the leaves were completely dry. The documentation was completed using bark picture and complete vegetative sample obtained from the field. Furthermore, the method used involved asking experts, Dr. Dwi Tyaningsih Adriyanti, and peer-to-peer review between researcher and local field expert, Mr. Dulhadi, as well as some references, including Ashton (1982) and Newman et al. (1996a, 1996b).

\section{Leaf characterization}

Each leaf sample was characterized following Leaf Architecture Working Group (1999). Leaf characters comprise 17 features extracted from single blade. An example of each part of the venation order is shown in Figure 2.

\section{Data analysis}

Data analysis protocol following Maulia (2020) where the leaves' morphological characters, including patterns, margin, length, and width were observed and measured. Subsequently, each species' leaf architecture species were characterized according to the written character. Each feature was then assigned a score according to the existing character. This score consists of various categories, depending on the existent character, meaning laminar category $0-4$. The score was then converted into binary numbers ( 0 and 1$)$ by standardizing the process. This was followed by analyzing the value using MVSP (Multivariate Statistical Package) application 2.1. Subsequently, the similarity of each was determined by SMC (Simple Matching Coefficient), using UPGMA algorithm
(Unweighted Pair Group Method with Arithmetic Means) as a clustering algorithm with dendrogram output. In addition, the determination key was formulated based on leaf architecture character. This analysis commonly used in clustering especially using morphological data (Hernandez et al. 2020).

\section{RESULTS AND DISCUSSION}

\section{Leaf character variation}

This study examined 17 leaf characters and identified the macroscopic leaf architecture variable in 35 species of Dipterocarpaceae comprising five genera, i.e. Dipterocarpus, Shorea, Parashorea, Hopea, and Dryobanalops (Table 1). The data shows that Dipterocarpaceae species share some similar characters, but also bring great variabilities among the leaf architectural character. All the species resemble two diagnostic characters of Ditperocarpacae: geniculated petiole and pinnate primary venation (Ashton 1982). The other 15 leaf architecture character represent the variability of leaf morphology on each species. The species laminar category varies. There is five-leaf category which spread among species studies, i.e. microphyll (225-2.025 $\left.\mathrm{mm}^{2}\right)$, notophyll (2.025-4.500 $\left.\mathrm{mm}^{2}\right)$, mesophyll (4.500-18.225 $\mathrm{mm}^{2}$ ), macrophyll (18.225-164.025 $\left.\mathrm{mm}^{2}\right)$, and megaphyll $\left(>16.025 \mathrm{~mm}^{2}\right)$. There are three-leaf shapes observed in the measurement process, i.e., elliptic, oblong, and ovate. In the observation of venation character, there are two groups based on their order, i.e. secondary and tertiary vein. Secondary vein comprises of three types, i.e. brochidodromous, craspedodromous, and weakly brochidodromous. Brochidodromous characterize the secondaries joined together in a series of prominent arches, the weakly brochidodromous share the same definition but the venation at the end of secondaries showing the weakened joint between the adjacent secondaries. Meanwhile, the craspedodromous describe the secondaries terminating the margin (Hickey 1975). The other characters describe the variability between the species.

Leaf architecture has been an important topic in taxonomy (Bucksch 2014), especially encountering flowering periodization (Jones 1986; Sack et al. 2008), and leaves as identification tools in the flowering plants are bound to be very useful in the future. The predicted leaf architecture is then reconstructed using computational modelling (Hussein et al. 2021) to identify severely degraded herbarium specimens (Little et al. 2014). The petiole anatomy has proven to be useful as an identification tool in Shorea spp. (Hernandez et al. 2020). Several Shorea species and Dipterocarpus gracilis have slightly geniculate petiole. The petiole has various anatomy and morphological shape between species, and is, therefore, is an important feature in identification. Paudel and Heo (2017) reported that the additional petiole feature in Ebenaceae possibly helps identify the species level, while Niinemets and Fleck (2002) showed that the petiole morphology is strongly connected with the physiological process in Liriodendron tilupifera. Dipterocarpaceae leaf 
varies in laminar size, and the size is reported to be plastic caused by environmental factors (Parkhurst and Loucks 1972). However, the manual minimized the environmental issue by providing a size range in each category.

In this study, the Dipterocarpus spp. showed mostly categorized as macrophyll-megaphyll sized leaves. The largest category is megaphyll, owned by Dipterocarpus elongatus, while the smallest leaf category is microphyll, owned by Shorea laevis. Further studies regarding leaf size are bound to help in distinguishing the process of cell division and expansion (Gallagher 1979). This study found that laminar shape varied between three laminar shapes, i.e., ovate, elliptic, and oblong. This study supports Ashton (1982) that species of Dipterocarpaceae is varied in laminar shape. Hopea spp. tend to have ovate laminar shape, while Shorea spp. has oblongous shape except in Shorea fallax, S. johorensis, S. multiflora, S. excelliptica, S. laevis, $S$. ovalis, $S$. platyclados, and $S$. pinanga. In addition, Dipterocarpus spp. and Dryobalanops spp. are mostly have ellipsoid laminar shapes.

Species of Dipterocarpaceae mostly have symmetrical leaves, but some species of Hopea spp. have asymmetric bases. According to Dengler and Tsukaya (2001), leaf symmetry helps to understand the link between leaf development and cell-specific traits. Most species have acute base angle, except $S$. compressa, S. kunstleri, and Hopea mangarawan with obtuse angle. The leaf apex varied between acute and acuminate, while the base shape varied between cordate, convex, rounded, and complex base. A leaf's shape is related to genetic traits and is hereditary also has a strong influence in determining species in the plant (Gailing et al. 2012). In this study, the species found mostly have entire margin, but some have bumpy margin, such as Dipterocarpus elongatus, $D$. grandiflorus, and D. hasseltii. Therefore, leaf margin is useful in distinguishing species (Badron et al. 2014) and possibly explains past paleotemperate conditions (Peppe et al. 2018).

Secondary venation is categorized into three kinds, i.e. craspedodromous, brochidodromous, and weakly brochidodromous. Craspedodromous describe where the leaves have secondaries terminating at the margin, while brochidodromous implies the secondaries joined together in a series of prominent arches. Weak brochidodromous resemble brochidodromous type, but with weaker vein joint.

\section{Cluster analysis}

All characters presented in Table 1 were used in cluster analysis to determine the similarity between objects of observation. The distance was created to facilitate research in identifying and grouping the species. Furthermore, the cluster analysis used UPGMA and Simple Matching Coefficient logarithms. After the cluster construction, the phenon was created at 0.695 similarity level to classify 35 species of Dipterocarpaceae into four major clusters (Figure 3); the Phenon was created to delineate groups in dendrogram, and create meaningful interpretation in the study.

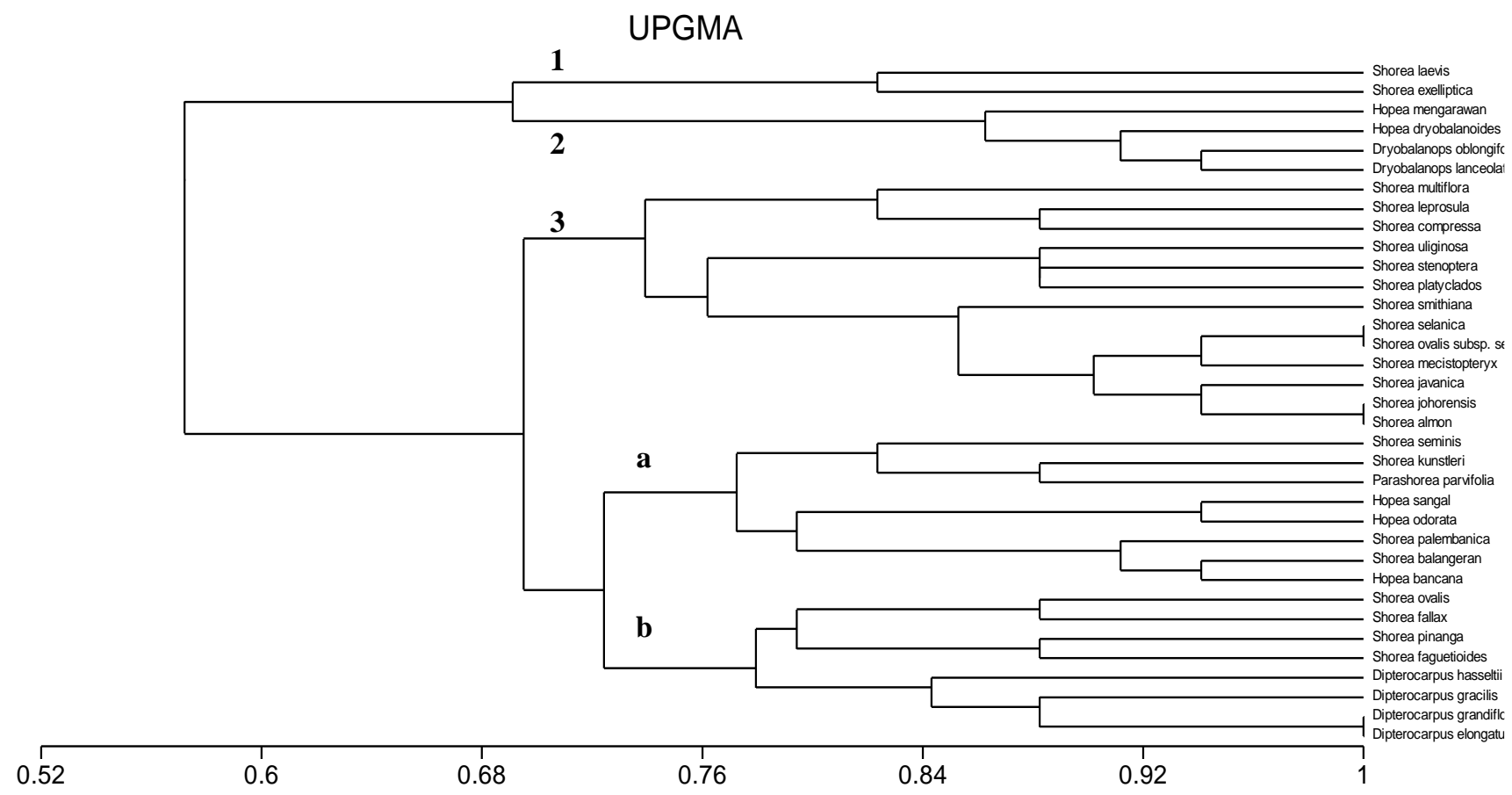

Simple Matching Coefficient

Figure 3. Cluster analysis based on leaf architecture character of 35 species of Dipterocarpaceae using UPGMA 
Table 1. Leaf architecture characters of 35 species of Dipterocarpaceae cultivated in Forest Area with Special Purposes (KHDTK) Carita, Banten, Indonesia

\begin{tabular}{|c|c|c|c|c|c|c|c|c|c|c|c|c|c|c|c|c|c|}
\hline Species & $\begin{array}{l}\text { (1) } \\
\text { PET }\end{array}$ & $\begin{array}{l}\text { (2) } \\
\text { LAM }\end{array}$ & $\begin{array}{l}\text { (3) } \\
\text { LSH }\end{array}$ & $\begin{array}{l}\text { (4) } \\
\text { LSY }\end{array}$ & $\begin{array}{l}\text { (5) } \\
\text { BNG }\end{array}$ & $\begin{array}{l}\text { (6) } \\
\text { BSH }\end{array}$ & $\begin{array}{l}\text { (7) } \\
\text { ASH }\end{array}$ & $\begin{array}{l}\text { (8) } \\
\text { LFM }\end{array}$ & $\begin{array}{l}\text { (9) } \\
\text { PVN }\end{array}$ & $\begin{array}{l}\text { (10) } \\
\text { SVN }\end{array}$ & $\begin{array}{l}\text { (11) } \\
\text { SVS }\end{array}$ & $\begin{array}{l}\text { (12) } \\
\text { SVA }\end{array}$ & $\begin{array}{l}\text { (13) } \\
\text { ISV }\end{array}$ & $\begin{array}{l}\text { (14) } \\
\text { TVN }\end{array}$ & $\begin{array}{l}\text { (15) } \\
\text { TVC }\end{array}$ & $\begin{array}{l}\text { (16) } \\
\text { TVA }\end{array}$ & $\begin{array}{l}\text { (17) } \\
\text { TVV }\end{array}$ \\
\hline Dipterocarpus elongatus Korth. & gon & meg & el & sym & ac & cor & $\mathrm{acm}$ & bum & pin & bro & uni & uni & abs & $\operatorname{mix}$ & $\sin$ & obt & uni \\
\hline Dipterocarpus gracilis Blume & sli & $\operatorname{mac}$ & el & sym & $\mathrm{ac}$ & cun & $\mathrm{acm}$ & ser & pin & cras & uni & uni & abs & $\operatorname{mix}$ & $\sin$ & obt & uni \\
\hline Dipterocarpus grandiflorus (Blanco) Blanco & gon & $\mathrm{mac}$ & el & sym & $\mathrm{ac}$ & cor & $\mathrm{acm}$ & bum & pin & bro & uni & uni & abs & $\operatorname{mix}$ & $\sin$ & obt & uni \\
\hline Dipterocarpus hasseltii Blume & gon & mes & obg & sym & $\mathrm{ac}$ & $\operatorname{cvx}$ & $\mathrm{acm}$ & bum & pin & bro & uni & uni & abs & $\operatorname{mix}$ & $\sin$ & obt & uni \\
\hline Dryobalanops lanceolata Burck & gon & not & el & sym & $\mathrm{ac}$ & $\operatorname{cvx}$ & $\mathrm{acm}$ & ent & pin & bro & uni & uni & str & alt & abs & ire & inc \\
\hline Dryobalanops oblongifolia Dyer & gon & not & obg & sym & $\mathrm{ac}$ & $\operatorname{cvx}$ & $\mathrm{acm}$ & ent & pin & bro & uni & uni & str & alt & abs & ire & inc \\
\hline Hopea mengarawan Miq. & gon & $\operatorname{mic}$ & ovt & sym & obt & $\mathrm{cvx}$ & $\mathrm{acm}$ & ent & pin & cras & uni & uni & str & alt & abs & obt & inc \\
\hline Hopea odorata Roxb. & gon & not & el & basy & $\mathrm{ac}$ & $\operatorname{cvx}$ & $\mathrm{ac}$ & ent & pin & webr & uni & uni & abs & $\operatorname{mix}$ & $\sin$ & obt & uni \\
\hline Hopea bancana (Boerl.) Slooten & gon & mes & ovt & basy & $\mathrm{ac}$ & $\operatorname{cvx}$ & $\mathrm{acm}$ & ent & pin & cras & uni & uni & abs & $\operatorname{mix}$ & $\sin$ & obt & uni \\
\hline Hopea dryobalanoides Miq. & gon & not & el & sym & $\mathrm{ac}$ & $\operatorname{cvx}$ & $\mathrm{acm}$ & ent & pin & cras & uni & uni & str & alt & abs & obt & inc \\
\hline Hopea sangal Korth. & gon & not & ovt & basy & $\mathrm{ac}$ & $\mathrm{cpl}$ & ac & ent & pin & webr & uni & uni & abs & $\operatorname{mix}$ & stra & obt & uni \\
\hline Parashorea parvifolia Wyatt-Sm. ex P.S.Ashton & gon & not & obg & sym & $\mathrm{ac}$ & $\mathrm{cvx}$ & $\mathrm{acm}$ & ent & pin & webr & uni & uni & str & $\operatorname{mix}$ & $\sin$ & obt & uni \\
\hline Shorea exelliptica Meijer & sli & mic & el & sym & $\mathrm{ac}$ & $\operatorname{cvx}$ & $\mathrm{ac}$ & ent & pin & webr & uni & uni & abs & $\operatorname{mix}$ & $\sin$ & obt & inc \\
\hline Shorea faguetioides P.S.Ashton & sli & mes & el & basy & $\mathrm{ac}$ & $\operatorname{cvx}$ & $\mathrm{acm}$ & ent & pin & webr & uni & uni & abs & $\operatorname{mix}$ & $\sin$ & obt & uni \\
\hline Shorea fallax Meijer & gon & mes & el & sym & $\mathrm{ac}$ & $\operatorname{cvx}$ & ac & ent & pin & bro & uni & uni & abs & $\operatorname{mix}$ & $\sin$ & obt & uni \\
\hline Shorea johorensis Foxw. & gon & $\operatorname{mac}$ & obg & sym & $\mathrm{ac}$ & rou & $\mathrm{acm}$ & ent & pin & bro & uni & uni & abs & mix & $\sin$ & obt & uni \\
\hline Shorea kunstleri King & gon & not & ovt & sym & obt & $\mathrm{cvx}$ & $\mathrm{acm}$ & ent & pin & webr & uni & uni & abs & $\operatorname{mix}$ & $\sin$ & obt & uni \\
\hline Shorea laevis Ridl. & sli & not & el & sym & $\mathrm{ac}$ & $\operatorname{cvx}$ & $\mathrm{acm}$ & ent & pin & webr & uni & uni & abs & alt & abs & ire & inc \\
\hline Shorea leprosula Miq. & sli & mes & obg & sym & $\mathrm{ac}$ & rou & $\mathrm{acm}$ & ent & pin & webr & uni & uni & abs & $\operatorname{mix}$ & $\sin$ & obt & uni \\
\hline Shorea mecistopteryx Ridl. & sli & $\operatorname{mac}$ & obg & sym & $\mathrm{ac}$ & cor & $\mathrm{acm}$ & ent & pin & bro & uni & $\mathrm{abr}$ & abs & $\operatorname{mix}$ & $\sin$ & obt & uni \\
\hline Shorea multiflora (Burck) Symington & sli & mes & ovt & sym & $\mathrm{ac}$ & rou & $\mathrm{acm}$ & ent & pin & webr & uni & $\mathrm{abr}$ & abs & opp & conv & per & uni \\
\hline Shorea ovalis Blume & sli & mes & el & sym & $\mathrm{ac}$ & $\mathrm{cvx}$ & $\mathrm{acm}$ & ent & pin & bro & uni & uni & abs & $\operatorname{mix}$ & $\sin$ & obt & uni \\
\hline Shorea ovalis subsp. sericea (Dyer) Ashton & gon & mes & obg & sym & $\mathrm{ac}$ & rou & $\mathrm{acm}$ & ent & pin & bro & uni & abr & abs & $\operatorname{mix}$ & stra & obt & uni \\
\hline Shorea palembanica Miq. & gon & mes & obg & basy & $\mathrm{ac}$ & $\operatorname{cvx}$ & $\mathrm{acm}$ & ent & pin & bro & uni & uni & abs & $\operatorname{mix}$ & $\sin$ & obt & uni \\
\hline Shorea platyclados Slooten ex Endert & gon & not & $\mathrm{el}$ & sym & $\mathrm{ac}$ & cor & $\mathrm{acm}$ & ent & pin & webr & $\mathrm{abr}$ & $\mathrm{abr}$ & wea & $\operatorname{mix}$ & $\sin$ & obt & uni \\
\hline Shorea selanica (Lam.) Blume & gon & mes & obg & sym & $\mathrm{ac}$ & rou & $\mathrm{acm}$ & ent & pin & bro & uni & $\mathrm{abr}$ & abs & mix & $\sin$ & obt & uni \\
\hline Shorea seminis Slooten & gon & mes & obg & sym & $\mathrm{ac}$ & $\mathrm{cpl}$ & $\mathrm{acm}$ & ent & pin & webr & uni & uni & abs & $\operatorname{mix}$ & conv & obt & uni \\
\hline Shorea smithiana Symington & gon & mac & obg & sym & $\mathrm{ac}$ & rou & $\mathrm{acm}$ & ent & pin & webr & uni & uni & wea & $\operatorname{mix}$ & $\sin$ & obt & uni \\
\hline Shorea stenoptera Burck & gon & $\operatorname{mac}$ & obg & sym & $\mathrm{ac}$ & cor & $\mathrm{acm}$ & ent & pin & webr & $\mathrm{abr}$ & $\mathrm{abr}$ & abs & $\operatorname{mix}$ & $\sin$ & obt & uni \\
\hline Shorea uliginosa Foxw. & gon & $\operatorname{mac}$ & obg & sym & $\mathrm{ac}$ & rou & $\mathrm{acm}$ & ent & pin & webr & $\mathrm{abr}$ & $\mathrm{abr}$ & wea & mix & $\sin$ & obt & uni \\
\hline Shorea almon Foxw. & gon & mes & obg & sym & $\mathrm{ac}$ & rou & $\mathrm{acm}$ & ent & pin & bro & uni & uni & abs & $\operatorname{mix}$ & $\sin$ & obt & uni \\
\hline Shorea balangeran Burck & gon & not & ovt & basy & $\mathrm{ac}$ & CVX & $\mathrm{ACM}$ & ent & pin & cras & uni & uni & abs & $\operatorname{mix}$ & $\sin$ & obt & uni \\
\hline Shorea compressa Burck & sli & mes & obg & sym & obt & or & & ent & pin & webr & uni & uni & abs & $\operatorname{mix}$ & $\sin$ & obt & uni \\
\hline Shorea javanica Koord. \& Valeton & gon & $\operatorname{mac}$ & obg & sym & ac & cor & $\mathrm{ACM}$ & ent & pin & webr & uni & uni & abs & $\operatorname{mix}$ & $\sin$ & obt & uni \\
\hline Shorea pinanga Scheff. & gon & mes & $\mathrm{el}$ & sym & $\mathrm{ac}$ & CVX & $\mathrm{ACM}$ & ent & pin & webr & uni & uni & abs & mix & $\sin$ & obt & uni \\
\hline
\end{tabular}

Note : (1) Petiole (PET): a) geniculated (gon), b) slightly geniculated (sli); (2) Laminar size (LAM): a) microphyll (mic), b) notophyll (not), c) mesophyll (mes), d) pinnate macrophyll (mac), e) megaphyll (meg); (3) Laminar shape (LSH): a) elliptic (el), b) oblong (obg), c) Ovate (ovt); (4) Laminar symmetry (LSY): a) symmetrical (sym), b) assymetrical at base (basy); (5) Base angle (BNG): a) acute (ac), b) obtuse (obt); 6) Base shape (BSH): a) cordate (cor), b) cuneate (cun), c) convex (cvx), d) complex (cpl), e) rounded (rou); (7) Apex shape (ASH): a) acute (ac), b) acuminate (acm); (8) Leaf margin (LFM): a) bumpy (bum), b) serrate (ser), c) entire (ent); (9) Primary vein (PVN): pinnate (pin); (10) Secondary vein (SVN): a) brochidodromous (bro), b) craspedodromous (cras), c) weakly brochidodromous (webr); (11) Secondary vein spacing (SVS): a) abruptly decreased toward base (abr), b) uniform (uni); (12) Secondary vein angle (SVA): a) abruptly increased torward base (abr), b) uniform (uni); (13) Intersecondary vein (ISV): a) strong (str), b) absent (abs), c) weak (wea); (14) Tertiary vein (TVN): a) mixed (mix), b) alternate (alt), c) opposite (opp); (15) Tertiary veni course (TVC): a) sinous (sin), b) admedially ramified (abs), c) convex (conv), d) straight (stra); (16) Tertiary vein angle (TVA): a) obtuse (obt), b) irregular (ire), c) perpendicular (per); (17) Tertiary vein variability (TVV): a) uniform (uni), b) inconsistent (inc) 
In general, all species studied have pinnate primary leaves and geniculate petiole. Most of the observations had mixed tertiary vein and the phenon line from the 35 different species into four clusters. These are small leaf (microphyll) category, inconsistent tertiary angle pattern toward the primary vein, symmetrical leaves with a round or cordate base, and do not resemble a combination of symmetrical leaf and rounded base. The first cluster consists of two species, i.e., Shorea laevis, which belongs to the notophyll category and S. excelliptica which has microphyll category. These two laminar size categories belonging to the small leaves group (Shougang et al. 2003) and the two species were easily differentiated from other species by unified the venation order $1^{\circ}, 2^{\circ}$, and $3^{\circ}$. Both $S$. laevis and $S$. excelliptica have pinnate on the $1^{\circ}$ venation, weakly brochidodromous on the $2^{\circ}$ venation, and mixed category for $3^{\circ}$ venation. Venation provides mechanical, defensive, and hydraulic functions (Blonder et al. 2018) in addition to the main function as a photosynthetic distributor and therefore plays a crucial role (Chung 2012). According to Sack and Scoffoni (2013), venation density contributes to the significance of gas and $\mathrm{K}$ exchange inside and out of the leaves, and this shows the significance of identifying the venation structure (Sack and Scoffoni 2013).

The second cluster had an inconsistent tertiary angle pattern toward the primary vein in Hopea mangarawan, $H$. dryobalanoides, Dryobalanops lanceolata, and D. oblongifolia with the characteristic of a secondary ladderlike venation (dryobalanoids). These secondary ladder-like venation are very significant in determining species of Dipterocarpaceae, because these characters only resemble certain species, including Hopea spp. and Dryobalanops spp. (Fernando et al. 2009; Poopath et al. 2017; Talip et al. 2017).

The third cluster had symmetrical leaves with a round or cordate base, and comprised thirteen species, i.e. Shorea multiflora, S. leprosula, S. compressa, S. uliginosa, S. stenoptera, S. platyclados, S. smithiana, S. selanica, S. ovalis subsp. sericea, S. mecistopteryx, S. javanica, $S$. johorensis,S. almon. The cordate base is found in other Shorea spp. such as Shorea palosapis and Shorea induplicata (Pulan and Buot Jr. 2014; Ashton 1982). Leaf symmetry could be diagnostic identification tool (Nelson and Dengler 1997; Villareal and Buot Jr. 2015). Dipterocarpaceae genus member, Vatica spp. represent strong asymmetrical laminar shape (Ashton 1982). The combination of some morphological characters are able to provide more specific analysis in plant identification (Viscosi and Cardini 2011). S. selanica, and S. ovalis subsp. sericea had the exact similarity index as $S$. ovalis subsp. sericea, implying the two species probably have a high resemblance. This is due to the character standardization process in the analysis. The similarity is affected by a binary number change, therefore, some objects are considered equal. However, these two species are distinguishable in the determination $S$. selanica has slightly curved venation, while $S$. ovalis subsp. sericea had a straight tertiary vein category. S. johorensis and $S$. almon also have a similarity index of about 1 . However, the two are distinguishable from the category of leaf size. In addition, $S$. johorensis has macrophyll leaf size, while $S$. almon has the nanophyll.

The fourth cluster's members do not resemble a combination of symmetrical leaf and rounded base, and include S. fallax, S. ovalis, S. pinanga, S. faguetioides, Dipterocarpus hasselti, D. gracilis, D. grandiflorus, and D. elongatus. In this study, all Dipterocarpus species generally have large leaf sizes, and were therefore covered by the fourth cluster (Maruyama et al. 1997). However, the result conforms with the prior description in Ashton (1982) where Shorea fallax indeed has symmetrical leaves, but the leaf base shape is wide obtuse. Meanwhile, Shorea ovalis has an oblong shape and obtuse base, which omits the species from the other three clusters. Shorea pinanga has a broadly cuneate and subcordate base, alike Shorea faguetioides which resemble the leaf base category. Rosdayanti et al. (2019) reported that the base shape category is a valuable character in the morphological delineation of Shorea species. In cluster four-node b, there are Dipterocarpus hasseltii, D. grandiflorus, and D. elongatus that share a similar leaf size range macrophyll and megaphylly (Figure 3). Leaf architecture in Dipterocarpaeae is a valuable descriptor in leaf fossil characterization (Lakhanpal and Guleria 1987). The report describes some main features in leaf fossils, there are leaf shape, apex, base shape, texture thickness, and secondary venation. The node a comprises Shorea seminis, S. kunstleri, S palembanica, S. balangeran, Parashorea parvifolia, Hopea sangal, $H$. odorata, and $H$. banana also share similar characters that omits them from the three major clusters. Base asymmetry and ovate-oblong leaf shape are the unifying characters in the nodes (Figure $3)$.

Qualitative and quantitative anatomical data could support the reliability of morphological data in leaf architecture, especially in classify species in conjunction with relevant molecular and ecological evidence (Talip et al. 2017). Leaf architecture remains a significant character to distinguish plants in species level. This approach could be the solution toward species where the generative part is uncertain to fulfill identification requirements. However, the leaf clearing procedure was not conducted in this study, due to the absence of tools with the capacity to clear bigsized leaves. Therefore, the leaf architecture variable requires further exploration, especially with regard to the microscopy variable of leaf venation. The $4^{\text {th }}$ and $5^{\text {th }}$ vein orders also need to be unveiled to ensure the data is more comprehensive. Further are also required to capture the image of whole leaf architecture character to provide imagery pattern data in all species to enhance preservation. Further studies are bound to be useful to paleobotanists while determining leave fossils based on the leaf architecture features.

\section{Determination key}

The determination key of 35 species of Dipterocarpaceae from the collected specimens based on the architectural characterization of leaves using the parallel key is shown as follows: 


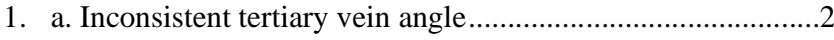

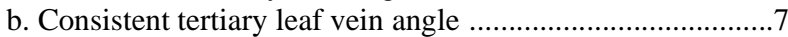

2. a. Geniculated petiole.

b. Slightly geniculate petiole.

3. a. Notophyll leaf category ...

category ..................... Hopea mengarawan

4. a. Brochidodromous secondary vein .........................................5

b. Craspedodromous secondary vein.....Hopea dryobalanoides

5. a. Elliptic leaf shape........................... Dryobalanops lanceolata

b. Oblong leaf shape........................Dryobalanops oblongifolia

6. a. Blunt tertiary leaf vein angle.......................Shorea exelliptica b. Irregular tertiary vein angle ............................Shorea laevis

7. a. Symmetrical leaf with rounded or cordate leaf base..............8

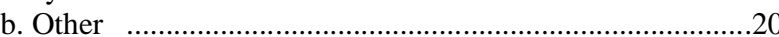

8. a. Mesophyll leaf category and primary vein hairy ..................9

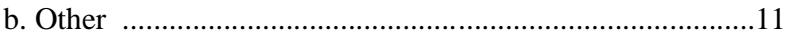

9. a. Secondary vein angle uniform ..........................................10 b. Secondary vein angle abruptly increases toward base ... ............................................. Shorea multiflora

10. a. Acute leaf base angle ................................Shorea leprosula b. Obtuse leaf base angle .............................Shorea compressa

11. a. Secondary vein spacing abruptly decrease toward base ....12 b. Secondary vein spacing uniform

12. a. Primary vein yellow-haired .........................Shorea uliginosa b. Primary vein glabrous …................................................13

13. a. Intersecondary vein exist ....................... Shorea platyclados b. Intersecondary vein absent ........................Shorea stenoptera

14. a. Weak intersecondary vein .......................Shorea smithiana b. String Intersecondary …................................................. 15

15. a. Secondary vein angle pattern abruptly increase toward base

................................................... 16

b. Secondary vein angle pattern uniform ….........................18

16. a. Cordate leaf shape ................................Shorea mecistopteryx

b. Rounded leaf shape .......................................................17

17. a. Straight tertiary vein category...Shorea ovalis subsp. sericea b. Curvy tertiary vein category ........................Shorea selanica

18. a. Primary vein brown-haired............................Shorea javanica b. Primary vein yellow-haired

a. Macrophyll leaf category b. Mesophyll leaf category .................................Shorea almon

20. a. Entire margin with geniculated petiole $\quad . . . \ldots \ldots \ldots \ldots \ldots . . . .21$ b. Not Entire margin with geniculated petiole $\quad$.............28

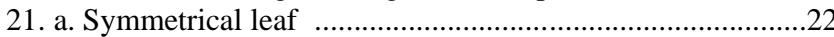

b. Leaf asymmetrical at base ….........................................24

22. a. Concave leaf base ...........................................................23

b. Complex leaf base ........................................Shorea seminis

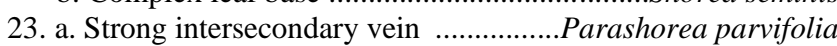
b. Intersecondary vein absent ..........................Shorea kunstleri

24. a. Weakly brochidodromous secondary vein ........................25 b. Other ...26

25. a. Elliptic leaf shape …….................................. Hopea sangal b. Ovate leaf shape Hopea odorata

26. a. Primary vein hair smooth b. Primary vein hair rough Shorea palembanica

27. a. Notophyll leaf category ............................ Shorea balangeran b. Mesophyll leaf category ................................ Hopea banana

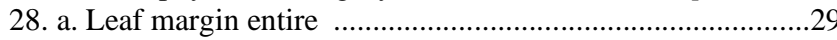

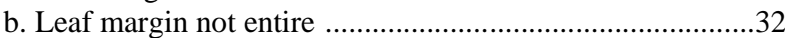

29. a. Brochidodromous secondary vein .......................................30

b. Weakly brochidodromous secondary vein .......................31

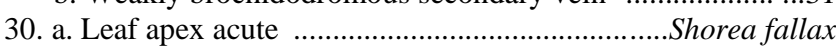
b. Leaf apex acuminate .....................................Shorea ovalis

31. a. Symmetrical leaf ........................................Shorea pinanga b. Leaf asymmetrical at base .....................Shorea faguetioides

32. a. Elliptic leaf shape ............................................................ 33 b. Oblong leaf shape ...........................Dipterocarpus hasseltii
33. a. Geniculated petiole ……................................................. 34

b. Slightly geniculate petiole ...............Dipterocarpus gracilis

34. a. Macrophyll leaf category ............Dipterocarpus grandiflorus

b. Megaphyll leaf category .................Dipterocarpus elongatus

In conclusion, the general characters of Dipterocarapaceae leaves are pinnate, geniculate petiole, and entire margin. Based on the 35 species of Dipterocarpaceae studied, they have grouped into four major clusters: the first group is the tiny (microphyll) leaf group category, the second group comprised species with inconsistent tertiary vein pattern, the third was characterized by leaves combining two features, symmetrical leaves with cordate base, while the last cluster was characterized by species resembling neither of the mentioned characters. The Phenon was cut at 0.695 similarity level, to establish a meaningful interpretation of the research. Furthermore, the key determination comprised 34 couplets. Therefore, further analysis on the leaf clearing method is required to provide a magnified view of the areolation and more variables in leaf architecture.

\section{ACKNOWLEDGEMENTS}

The author would like to thank the Centre of Forest Research and Development, Bogor, Indonesia especially Dulhadi and team who helped to collect samples in the field. We also would like to deliver gratitude to colleagues for helpful discussion on the manuscript, also RTA (Theses Recognition) fund which helped us to publish the article in Biodiversitas.

\section{REFERENCES}

Appanah S. 1998.Management of Natural Forest. In: Appanah S, Turnbull JM (eds.) A Review of Dipterocarps: Taxonomy, Ecology and Silviculture. Center for International Forestry Research, Bogor

Ashton PS 1982. Dipterocarpaceae. In: van Steenis CGGJ (ed) Flora Malesiana (9): 237-552.

Baron UH, Talip N, Mohamad AL, Affenddi AEA, Juhari AAA. 2014. Studies on leaf venation in selected taxa of the genus Ficus L. (Moraceae) in Peninsular Malaysia. Trop Life Sci Res 25(2): 111125.

Balduzzi M, Binder BM, Bucksch A, Chang C, Hong L, Iyer-Pascuzzi AS, Pradal C, Sparks EE. 2017. Reshaping plant biology: Qualitative and quantitative descriptors for plant morphology. Front Plant Sci 8: 117. DOI: $10.3389 /$ fpls.2017.00117.

Barral A, Gomez B, Feild TS, Coiffard C, Daviero-Gomez V. 2013. Leaf architecture and ecophysiology of an early basal eudicot from the Early Cretaceous of Spain. Bot J Linn Soc 173(4): 596-605. DOI: 10.1111/boj.12095.

Blonder B, Salinas N, Bentley LP, Shenkin A, Chambi Porroa PO, Valdez Tejeira Y, Boza Espinoza TE, Goldsmith GR, Enrico L, Martin R, Asner GP, Díaz S, Enquist BJ, Malhi Y. 2018. Structural and defensive roles of angiosperm leaf venation network reticulation across an Andes-Amazon elevation gradient. J Ecol 106 (4): 16831699. DOI: $10.1111 / 1365-2745.12945$.

Bucksch A. 2014. A practical introduction to skeletons for the plant sciences. Appl Plant Sci 2 (8): 1-10. DOI: 10.3732/apps.1400005.

Buot Jr. IE. 2020. Leaf architecture as a promising tool in confirming of confusing plant taxa. J Nat Stud 19 (1): 134-143 
Celadiña DA, But. Jr. IE, Madulid DA, Evangelista TT, Tandang DN. 2012. Leaf architecture of selected Philippine Cinnamomum Scheff (Lauraceae) species. Thai Nat Hist Museum J 6 (2): 89-111.

Chung RCK. 2012. Systematic significance of leaf venation in genus Byttneria Linn. (Sterculiaceae). Malaysian International Biological Symposium. Universiti Putra Malaysia. Serdang.

Dayanandan S, Ashton PS, Williams SM, Primack RB. 1999. Phylogeny of the tropical tree family Dipterocarpaceae based on nucleotide sequences of the chloroplast rbcL gene. Am J Bot 86(8): 1182-1190. DOI: $10.2307 / 2656982$.

Dengler NG, Tsukaya H. 2001. Leaf morphogenesis in Dicotyledons: Current issues. Int J Plant Sci 162 (3): 459-464. DOI: 10.1086/320145

Dickinson TA, Parker WH, Strauss RE. 1987. Another approach to leaf shape comparisons. Taxon 36 (1): 1-20. DOI: 10.2307/1221345.

Fernando ES, Bande MJM, Piollo R, Sopot DD, Dolotina NE, Granert WG. 2009. Dipterocarpaceae of Bohol Island. Asia Life Sci 18 (1): 121-138.

Gailing O, Lind J, Lilleskov E. 2012. Leaf morphological and genetic differentiation between Quercus rubra L. and Q. ellipsoidalis E.J. Hill populations in contrasting environments. Plant Syst Evol 298 (8): 1533-1545. DOI: 10.1007/s00606-012-0656-y.

Gallagher JN. 1979. Field studies of cereal leaf growth. J Exp Bot 30(4) 657-668. DOI: 10.1093/jxb/30.4.625.

Hernandez JO, Maldia LS, Pulan DE, Buot Jr. IE, Park BB. 2020. Leaf architecture and petiole anatomy of Philippine Dipterocarpus species (Dipterocarpaceae). Bangladesh J Plant Taxon 27(1): 1-14. DOI: 10.3329/bjpt.v27i1.47564.

Hickey LJ. 1973. Classification of the architecture of Dicotyledonous leaves. Am J Bot 60(1): 17-33. DOI: 10.1002/j.15372197.1973.tb10192.x.

Hickey, LJ, Wolfe, JA. 1975. The bases of angiosperm phylogeny: vegetative morphology. Annals of the Missouri Botanical Garden, 538-589. DOI: $10.2307 / 2395267$

Hickey, LJ, Ash, A, Ellis, B, Johnson, K, Wilf, P, Wing, S. 1999. Manual of Leaf Architecture. Morphological description and categorization of dicotyledonous and net-veined monocotyledonous angiosperms. Washington: Leaf Architecture Working Group. DOI: 10.13140/2.1.3674.5282.

Huiet L, Li FW, Kao TT, Prado J, Smith AR, Schuettpelz E, Pryer KM. 2018. A worldwide phylogeny of Adiantum (Pteridaceae) reveals remarkable convergent evolution in leaf blade architecture. Taxon 67(3): 488-502. DOI: 10.12705/673.3.

Hussein BR, Malik OA, Ong WH, Slik JWF. 2021. Reconstruction of damaged herbarium leaves using deep learning techniques for improving classification accuracy. Ecol Inform 61: 101243 10.1016/j.ecoinf.2021.101243.

Inamdar JA, Murthy GSR. 1978. Leaf architecture in some Solanaceae. Flora 167(3-4): 265-272. DOI: 10.1016/S0367-2530(17)31118-0

Jessica B, Buot Jr. IE. 2014. Leaf architecture of ten species of Philippine Terminalia Linn. (Combretaceae). Intl Res J Biol Sci

3(3): 83-88

Jones JH. 1986. Evolution of the Fagaceae: The implications of foliar features. Ann Missouri Bot Gard 73(2): 228-275. DOI: $10.2307 / 2399112$

Kareem A, Jaskani MJ, Mehmood A, Khan IA, Awan FS, Sajid MW 2018. Morpho-genetic profiling and phylogenetic relationship of guava (Psidium guajava L.) as genetic resources in Pakistan. Rev Bras Frantic 40 (4): 1-11. DOI: 10.1590/0100-29452018069.

Lakhanpal RN, Guleria JS. 1987. Fossil leaves of Dipterocarpus from the Lower Siwalik beds near Jawalamukhi, Himachal Pradesh. Palaeobotanist 35: 258-262. DOI: 14.139.63.228.

Leaf Architecture Working Group. 1999. Manual of leaf architecture. Smithsonian Institution, Washington, DC

Little SA, Green WA, Wing SL, Wilf P. 2014. Reinvestigation of leaf rank, an underappreciated component of Leo Hickey's legacy. Bul Peabody Mus Nat Hist 55 (2): 79-87. DOI: 10.3374/014.055.0202.

Maruyama Y, Toma T, Ishida A, Matsumoto Y, Morikawa Y, Ang LH, Iwasa M. 1997. Photosynthesis and water use efficiency of 19 tropical tree species. J Trop For Sci 9 (3): 434-438.

Masungsong LA, Belarmino MM, Buot Jr. IE. 2019. Delineation of the selected Cucumis L. species and accessions using leaf architecture characters. Biodiversitas 20 (3): 629-635. DOI: 10.13057/biodiv/d200303.

Maulia Z. 2020. Identification and Characterization of Aquilaria spp. and Grynops verstegii (Gilg.) Domke in Indonesia Based on Lea
Architecture and ISSR Marker. [Thesis]. Universitas Gadjah Mada, Yogyakarta. [Indonesian]

Mazo KRF, Tribal LG. 2020. Elucidating differences between two confusing Shorea contorta S.Vid and Pentacme mindanensis Fox. species of Dipterocarpaceae via leaf morphometrics: An initial investigation. Bangladesh J Plant Taxon 27(2): 461-465. DOI: 10.3329/bjpt.v27i2.50685

Mishra MK, Padmajyothi D, Prakash NS, Ram AS, Srinivasan CS Sreenivasan MS. 2010. Leaf architecture in Indian coffee (Coffea arabica L.) cultivars and their adaptive significance. World J Fungal Plant Biol 1 (2): 37-41.

Nelson T, Dengler N. 1997. Leaf vascular pattern formation. The Plant Cell 9 (7): 1121. DOI: 10.1105/tpc.9.7.1121.

Newman MF, Burgess PF, Whitmore TC. 1998. Manuals of Dipterocarps for Foresters: Java to New Guinea. Center for International Forestry Research, Jakarta.

Newman MF, Burgess PF, Whitmore TC. 1996a. Manuals of Dipterocarps for Foresters: Borneo Island Light Hardwoods. Center for International Forestry Research, Jakarta.

Newman MF, Burgess PF, Whitmore TC. 1996b. Manuals of Dipterocarps for Foresters: Sumatra Medium and Heavy Hardwoods. Center for International Forestry Research, Jakarta.

Niinemets Ü, Fleck S. 2002. Petiole mechanics, leaf inclination, morphology, and investment in support in relation to light availability in the canopy of Liriodendron tulipifera. Oecologia 132(1): 21-33. DOI: $10.1007 / \mathrm{s} 00442-002-0902-\mathrm{z}$

Parkhurst DF, Loucks OL. 1972. Optimal leaf size in relation to environment. J Ecol 60(2): 505-537. DOI: 10.2307/2258359.

Paul N, Heo K. 2017. Morphology and anatomy: leaf, petiole and seed of Diospyros kaki Thunb. (Ebenaceae). Intl J Sci Reports 4(1): 1. DOI: 10.18203/issn.2454-2156.IntJSciRep20175934.

Peppe DJ, Baumgartner A, Flynn A, Blonder B. 2018. Reconstructing paleoclimate and paleoecology using fossil leaves. In: Methods in Paleoecology. Springer, Cham. DOI: 10.31233/osf.io/stzuc

Poopath M, Sookchaloem D, Duangjai S, Pooma R. 2017. Hopea macrocarpa (Dipterocarpaceae), a new species from peninsular Thailand. Thai For Bull 45 (2): 94-98. DOI: $10.20531 / \mathrm{tfb} .2017 .45 .2 .02$

Plan DE., Buot Jr. IE. 2014. Leaf architecture of Philippine Shorea species (Dipterocarpaceae). Intl Res J Biol Sci 3 (5): 19-26.

Purwaningsih. 2004. Ecological distribution of Dipterocarpaceae species in Indonesia. Biodiversitas 5(2): 89-95. [Indonesian] DOI: 10.13057/biodiv/d050210

Rimbawanto A. 2006. Conservation and Genetic Improvement of Indigenous Tree Species of Tropical Rain Forest of Indonesia: Technical Report ITTO PD 106/01 Rev. 1(F). ITTO and Faculty of Forestry, Gadjah Mada University, Yogyakarta

Rosdayanti H, Siregar UJ, Siregar IZ. 2019. Leaf morphology traits of Shorea spp. in Ex-Situ KHDTK Haurbentes. Media Konservasi 24(2): 207-215. DOI: 10.29244/medkon.24.2.207-215. [Indonesian]

Roth-Nebelsick A, Uhl D, Mosbrugger V, Kerp H. 2001. Evolution and function of leaf venation architecture: a review. Ann Bot 87 (5): 553 566. DOI: 10.1006/anbo.2001.1391.

Rugayah, Widjaja EA, Praptiwi. 2004. Guidelines for Collecting Data on Flora Diversity. Research Center for Biology, Indonesian Institute of Sciences, Bogor. [Indonesian]

Sack L, Dietrich EM, Streeter CM, Sánchez-Gómez D, Holbrook NM. 2008. Leaf palmate venation and vascular redundancy confer tolerance of hydraulic disruption. Proc Natl Acad Sci USA 105 (5): 1567-1572. DOI: 10.1073/pnas.0709333105.

Sack L, Scoffoni C. 2013. Tansley review leaf venation: Structure, function, development, evolution, ecology and application in the past, present and future. New Phytol 198: 983-1000. DOI: 10.1111/nph.12253.

Schmidt FH, Ferguson JHA. 1951. Rainfall types based on wet and dry period ratios for Indonesia with Western New Guinee. Kementerian Perhubungan, Djawatan Meteorologi dan Geofisik, Jakarta

Shougang H, Beck CB, Deming W. 2003. Structure of the earliest leaves: adaptations to high concentrations of atmospheric $\mathrm{CO}_{2}$. Intl $\mathrm{J}$ Plant Sci 164: 71-75. DOI: 10.1086/344557

Swaminathan C, Rao V, Shashikala S. 2012. Preliminary evaluation of variations in anatomical properties of Melia dubia Cav. wood. Intl Res J Biol Sci 1 (4): 1-6.

Talip N, Cutler DF, Ahmad Puad AS, Ismail BS, Ruzi AR, Ahmad Juhari AA. 2017. Diagnostic and systematic significance of petiole anatomy 
in the identification of Hopea species (Dipterocarpaceae). South Afr J Bot 111: 111-125. DOI: 10.1016/j.sajb.2017.03.008.

Thielges B, Sastrapradja SD, Rimbawanto A. 2001. In situ and ex situ conservation of commercial tropical trees. Proceedings of the International Conference on ex-situ and in situ Conservation of Commercial Tropical Trees. ITTO and Faculty of Forestry Gadjah Mada University, Yogyakarta, 11-13 June 2001.

Villareal AGM, Buot JrIE. 2015. Leaf architecture of Hoya incrassata Warb. and Hoya crassicaulis Elmer x Kloppenb.(Apocynaceae): Taxonomic identification and conservation concerns. Intl J Biodivers Conserv 15 (1): 203-213. DOI: 10.7718/sec.v15i1.1002.
Viscosi V, Cardini A. 2011. Leaf morphology, taxonomy and geometric morphometrics: a simplified protocol for beginners. PLoS One 6 (10): e25630. DOI: 10.1371/journal.pone.0025630.

Whitmore TC. 1962. Studies in systematic bark morphology: I. Bark morphology in Dipterocarpaceae. New Phytol 61 (2): 191-207. DOI: 10.1111/j.1469-8137.1962.tb06288.x.

Whitmore TC. 1984. Tropical Rain Forests of the Far East. Clarendon Press, Oxford. 